\title{
Effect of Fertility Levels and Stress Mitigating Chemicals on Nutrient Uptake, Yield and Quality of Mungbean [Vigna radiata (L.) Wilczek] under Loamy Sand Soil of Rajasthan
}

\author{
Sarita $^{1}$, O.P. Sharma ${ }^{2}$, U.N. Shukla ${ }^{1}$, Saroj Kumari Yadav ${ }^{3}$ and Roshan Kumawat $^{4}$ \\ ${ }^{1}$ Department of Agronomy, College of Agriculture, Jodhpur, Rajasthan, India \\ ${ }^{2}$ Department of Agronomy, SKN College of Agriculture, Jobner, Rajasthan, India \\ ${ }^{3}$ Department of Agronomy, RARI (SKNAU, Jobner), Rajasthan, India \\ ${ }^{4}$ Department of Agronomy, College of Agriculture, Ummedganj, Kota, India \\ *Corresponding author
}

\section{A B S T R A C T}

\section{Keywords}

Thiourea, Stress mitigating chemicals, Flower initiation, SA (Salicylic acid)

Article Info

Accepted:

10 April 2019

Available Online:

10 May 2019
A field experiment was conducted during kharif season of 2017 on loamy sand soil to study the Effect of Fertility Levels and Stress Mitigating Chemicals on productivity of Mungbean [Vigna radiata (L.) Wilczek]. The experiment consisted of four fertility levels [control $\left.\left(\mathrm{F}_{0}\right), 50 \% \operatorname{RDF}\left(\mathrm{F}_{1}\right), 75 \% \operatorname{RDF}\left(\mathrm{F}_{2}\right), 100 \% \operatorname{RDF}\left(\mathrm{F}_{3}\right)\right]$ and four stress mitigating chemicals [control $\left(\mathrm{S}_{0}\right), \mathrm{SA} @ 75 \mathrm{ppm}$ at flower initiation and 7 days after first spray $\left(\mathrm{S}_{1}\right)$, SA@75 ppm + 2\% Urea at flower initiation $\left(S_{2}\right)$ and Thiourea @ 500 ppm $\left.\left(S_{3}\right)\right]$. Results indicated that the application of $75 \%$ RDF being at par with $100 \%$ RDF, significantly increased the phosphorus concentration and total P- uptake, total K- uptake. However, in respect of $\mathrm{N}$ concentration in seed and straw and its uptake and protein content in seed, seed $\left(1077 \mathrm{~kg} \mathrm{ha}^{-1}\right)$, straw $\left(2279 \mathrm{~kg} \mathrm{ha}^{-1}\right)$ and biological yield (3356 kg ha $\left.{ }^{-1}\right), 100 \% \mathrm{RDF}$ excelled over all other treatments. Results further revealed that among stress mitigating chemicals 500 ppm thiourea remaining at par with SA $+2 \%$ Urea significantly higher seed $\left(1048 \mathrm{~kg} \mathrm{ha}^{-1}\right)$, straw $\left(2276 \mathrm{~kg} \mathrm{ha}^{-1}\right)$ and biological yield $\left(3324 \mathrm{~kg} \mathrm{ha}^{-1}\right)$, protein content, nitrogen and phosphorus concentration and their uptake $\mathrm{K}$ - uptake of mungbean over SA and control.

\section{Introduction}

Mungbean [Vigna radiata (L.) Wilczek] is a self pollinated leguminous crop which is grown during kharif as well as summer season in arid and semi arid regions. It is tolerant to drought and can be grown successfully on well drained loamy to sandy loam soils even in the areas of erratic rainfall.
Mungbean is a legume, it has the capacity to fix atmospheric nitrogen by its effective root nodules. The major part of nitrogen is met through Rhizobium present in the root nodules. Hence, crop requires starter dose of additional nitrogen for its initial growth and development. 
In terms of significance, phosphorus is the most indispensable mineral nutrient for legume crops as it helps in better root growth and development and thereby making them more efficient in biological nitrogen fixation (BNF). Nitrogen, phosphorus, potassium uptake by crop was also relatively higher with RDF. This was mainly due to higher biological production under these fertility levels.

The application of stress mitigating chemicals might prove beneficial in crop tolerance to adverse conditions. Thiourea is an important sulphydral compound which contains one $\mathrm{SH}$ group and is known to bring marked biological activity in plants. Foliar spray of thiourea has been reported not only to improve growth and development of plants but also the dry matter partitioning for increased grain yield (Arora, 2004).

Salicylic acid (SA) is a naturally occurring plant hormone acting as an important signalling molecule which adds to tolerance against abiotic stresses. It plays a vital role in plant growth, ion uptake and transport. This positive effect of SA could be attributed to an increased $\mathrm{CO}_{2}$ assimilation, photosynthetic rate and increased mineral uptake by the stressed plant under SA treatment.

These signaling molecules activate a range of signal transduction pathways, some of which relieve the plant to overcome stress. However, the physiological and biochemical basis of plants to unfavorable conditions induced by SA are yet to be clearly understood. Application of these stress mitigating chemicals in conjunction with fertilizer doses might provide a best management practice in order to understand the proven technology. Since, under such situation, the crop response to fertilizer application varies due to deficit moisture or uncertain weather conditions.

\section{Materials and Methods}

\section{Experimental site and climate}

An experiment was conducted at Agronomy farm, S.K.N. College of Agriculture, Jobner in Jaipur district of Rajasthan during kharif season of 2017 on loamy sand soil. Geographically, Jobner is situated $45 \mathrm{~km}$ west of Jaipur at $26^{\circ} 05^{\prime}$ North latitude, $75^{\circ} 28^{\prime}$ East longitude and at an altitude of 427 meters above mean sea level.

The area falls in agro-climatic zone-III a (Semi-arid Eastern Plain Zone) of Rajasthan. The climate of this region is a typically semiarid, characterized by extremes of temperature during both summer and winter. The average annual rainfall of this tract varies from $250 \mathrm{~mm}$ to $300 \mathrm{~mm}$ and is mostly received during the months of July to September.

During summer, temperature may go as high as $46^{\circ} \mathrm{C}$ while in winter, it may fall as low as $1.5{ }^{0} \mathrm{C}$. There is hardly any rain during winter and summer. The climate affects the growth, yield and quality of agricultural product. During crop season witnessed a rainfall of $147 \mathrm{~mm}$. The mean daily maximum and minimum temperatures during the growing season of mungbean fluctuated between 29.4 to $36.6^{\circ} \mathrm{C}$ and 18.4 to $26.6^{\circ} \mathrm{C}$, respectively. Similarly, mean daily relative humidity ranged between 37 to 81 per cent.

\section{Properties of soil of the experimental field}

The soil of the experimental field was loamy sand in texture, alkaline in reaction $\left(\mathrm{P}^{\mathrm{H}}-8.2\right)$, poor in organic carbon $(0.18 \%)$, low in available nitrogen $\left(128.3 \mathrm{~kg} \mathrm{ha}^{-1}\right)$ and medium in phosphorus $\left(16.23 \mathrm{~kg} \mathrm{ha}^{-1}\right)$ and potassium $\left(154.26 \mathrm{~kg} \mathrm{ha}^{-1}\right)$. 


\section{Experimental detail and treatment}

The experiment consisted of four fertility levels control $\left(\mathrm{F}_{0}\right), 50 \%$ RDF $\left(\mathrm{F}_{1}\right), 75 \% \mathrm{RDF}$ $\left(\mathrm{F}_{2}\right), 100 \% \operatorname{RDF}\left(\mathrm{F}_{3}\right)$ and stress mitigating chemicals control $\left(\mathrm{S}_{0}\right), \mathrm{SA} @ 75 \mathrm{ppm}$ at flower initiation and 7 days after first spray $\left(\mathrm{S}_{1}\right), 75 \mathrm{ppm} \mathrm{SA}+2 \%$ Urea at flower initiation $\left(\mathrm{S}_{2}\right)$ and $500 \mathrm{ppm}$ Thiourea $\left(\mathrm{S}_{3}\right)$. The total 16 treatment combinations were tested in factorial randomized block design with three replications; plot size was $4 \mathrm{~m} \mathrm{x}$ $3.6 \mathrm{~m}$ for crop; seed rate is $15-20 \mathrm{~kg}$ ha-1. mungbean was sown on 6th July 2017. Fertilizers were applied as per treatment through diammonium phosphate (DAP) containing $46 \% \quad \mathrm{P}_{2} \mathrm{O}_{5}$ and $18 \% \mathrm{~N}$ and urea containing $46 \% \mathrm{~N}$ at the time of sowing as per treatment. Thiourea and salicylic acid treatments were administered as foliar spray with 500 lit water per hactare. Foliar spray of thiourea@500 ppm applied as 500 mg/liter and salicylic acid $75 \mathrm{ppm}$ as $75 \mathrm{mg}$ /liter was done at flower initiation and salicylic acid + $2 \%$ urea at flower initiation and salicylic acid 75 ppm 7 days after first spray.

\section{Analysis of nutrient content, uptake and quality parameters}

\section{Nitrogen concentration and its uptake}

Nitrogen was estimated by digesting plant samples with $2 \mathrm{ml}$ concentrated sulphuric acid using hydrogen peroxide for removing black colour. Estimation of nitrogen was done by colorimetric method using Nessler's reagent to develop colour (Snell and Snell, 1949). Nitrogen concentration was calculated and expressed in percentage. The uptake of nitrogen by crop was calculated using following formula:

$$
\mathrm{N} \text { uptake }\left(\mathrm{kg} \mathrm{ha}^{-1}\right)=\frac{\begin{array}{c}
\text { Per cent N in seed } \mathrm{x} \\
\text { seed yield }\left(\mathrm{kg} \mathrm{ha}^{-1}\right)
\end{array}+\quad \begin{array}{l}
\text { percent N in Straw X } \\
\text { Straw yield }\left(\mathrm{kg} \mathrm{ha}^{-1}\right)
\end{array}}{100}
$$

\section{Phosphorus concentration and its uptake}

The seed and straw samples were analyzed for phosphorus concentration by Vanadomolybdo phosphoric yellow colour method in sulphuric acid system (Richards, 1954). The uptake of phosphorus by crop was calculated using following formula:

$\mathrm{P}$ uptake $\left(\mathrm{kg} \mathrm{ha}^{-1}\right)=$

$\mathrm{P}$ conc. in seed $(\%) \mathrm{X}$ Seed yield $\left(\mathrm{kg} \mathrm{ha}^{-1}\right)+\mathrm{P}$ conc. in straw (\%) X Straw yield $\left(\mathrm{kg} \mathrm{ha}^{-1}\right)$

\section{Potassium concentration and its uptake}

Potassium concentration in seed and straw was estimated by flame photometer method (Jackson, 1973). The uptake of potassium by crop was calculated using following formula:

$\mathrm{K}$ uptake $\left(\mathrm{kg} \mathrm{ha}^{-1}\right)=$

$\mathrm{K}$ conc. in seed $(\%) \mathrm{X}$ Seed yield $\left(\mathrm{kg} \mathrm{ha}^{-1}\right)+\mathrm{K}$ conc. in straw (\%) X Straw yield $\left(\mathrm{kg} \mathrm{ha}^{-1}\right)$ 


\section{Total nutrient uptake}

The total uptake of nitrogen, phosphorus and potassium was computed from $\mathrm{N}, \mathrm{P}$ and $\mathrm{K}$ concentration in seed and straw at harvest using following relationship:

Total uptake $\left(\mathrm{kg} \mathrm{ha}^{-1}\right)=$

Nutrient conc. in seed (\%) x yield $\left(\mathrm{kg} \mathrm{ha}^{-1}\right)+$ Nutrient conc. in straw (\%)x Straw yield $\left(\mathrm{kg} \mathrm{ha}^{-1}\right)$

\section{Protein content in seed}

Protein content in seed was calculated by multiplying nitrogen concentration (\%) in seed by the factor 6.25 (A.O.A.C., 1960).

\section{Results and Discussion}

\section{Effect on nitrogen content and uptake}

Improved nutritional environment in the rhizosphere as well as in the plant system leading to enhanced translocation of N, P and $\mathrm{K}$ in plant parts. Since the nutrient uptake is a function of its content in crop plant and seed and straw yield of the crop. The increase in these parameters due to $\mathrm{N}$ and $\mathrm{P}$ fertilization led to an increased uptake of nutrients in the present study. The data showed that increasing fertility levels increased the nitrogen concentration in seed and straw up to maximum dose. Application of $100 \%$ RDF improved the $\mathrm{N}$ concentration in seed $(4.01 \%)$ by over control, $50 \%$ and $75 \%$ RDF. Data further revealed that $\mathrm{N}$ concentration in straw $(1.50 \%)$ also showed the similar pattern with increasing level of fertilizer up to $100 \% \mathrm{RDF}$. A perusal of data indicated that total nitrogen uptake significantly increased due to different fertility levels as compared to control and the significantly highest $\mathrm{N}$ uptake was registered at $100 \%$ RDF. Enhancement in total nitrogen uptake due to $100 \% \operatorname{RDF}\left(81.02 \mathrm{~kg} \mathrm{ha}^{-1}\right)$ as compared to control $\left(\mathrm{F}_{0}\right), 50 \% \mathrm{RDF}\left(\mathrm{F}_{1}\right)$ and $75 \% \operatorname{RDF}\left(\mathrm{F}_{2}\right)$ was to the tune of $39.92,18.85$ and $6.94 \mathrm{~kg} \mathrm{ha}^{-1}$ which corresponded to 97.12 ,
30.32 and $9.36 \%$, respectively. These results are in cognizance with the findings of Sasode (2008) and Rathore et al., (2010).

Thiourea application might have helped in improvement of metabolic processes of plants and better growth and development, leading to greater absorption of nutrients from rhizosphere, it might be due to metabolic role of SH-group in root physiology and biochemistry. Data (Table 1) revealed that nitrogen concentration in seed and straw of mungbean was influenced significantly by stress mitigating chemicals over control. Foliar application of $500 \mathrm{ppm}$ thiourea at flower initiation $\left(S_{3}\right)$ estimated the maximum nitrogen concentration in seed $(22.22 \%)$ and proved superior over rest of the treatments except SA+2\% Urea. The similar trend was also observed with nitrogen concentration in straw. The corresponding enhancement due to thiourea over control and SA alone was to the extent of 38.83 and $5.92 \%$. Data further revealed that the spray of different chemicals brought about significant improvement in nitrogen uptake by mungbean over control. The maximum total nitrogen uptake was recorded with thiourea $\left(73.98 \mathrm{~kg} \mathrm{ha}^{-1}\right)$ which proved significantly superior to control and $75 \mathrm{ppm}$ SA by 53.80 and $11.85 \%$, respectively and remained at par with $\mathrm{SA}+$ $2 \%$ Urea. The per cent increase in total $\mathrm{N}$ uptake due to application of SA $+2 \%$ Urea and SA over control was 45.82 and $37.50 \%$, respectively. Thiourea creates better microbial population in soil which is responsible to 
mobilize essential nutrients. These results are in close conformity with the findings of Lakhana et al., (2005) and Yadav (2005).

\section{Effect on phosphorus content and uptake}

Phosphorus is the most indispensable mineral nutrient for legume crops as it helps in better root growth and development and thereby making them more efficient in biological nitrogen fixation (BNF). Phosphorus is an essential constituent of nucleic acid (RNA and DNA), ADP and ATP, nucleoproteins, amino acid, protein, several co-enzymes (NADP), viz., thiamine and pyrodoxyl phosphate. The data (Table 1) showed that increasing fertility levels significantly increased the phosphorus concentration in seed and straw. Application of $75 \%$ RDF being at par with 100\% RDF recorded significantly higher phosphorus concentration in seed and straw, indicating an increase of 74.81 and $9.66 \%$ in seed and 98.13 and 10.41 $\%$ in straw over control and 50\% RDF, respectively. A perusal of data (Table1) indicated that total phosphorus uptake was found to be significantly higher under $75 \%$ RDF (9.87 kg ha ${ }^{-1}$ over 50\% RDF (8.09 kg ha ${ }^{1}$ ) and control (3.99 kg ha $\left.{ }^{-1}\right)$. The increase in $\mathrm{P}$ uptake due to $75 \% \mathrm{RDF}$ in terms of $\mathrm{kg}$ ha ${ }^{1}$ was 5.88 and 1.78 over control and 50\% RDF, respectively and it also remained at par with $100 \%$ RDF. The present results are also in agreement with the findings on legume crops work has been done by several workers (Singh and Pareek, 2003, Yakadri et al., 2004).

Data (Table 1) also revealed that phosphorus concentration in seed and straw was influenced significantly by stress mitigating chemicals over control. Foliar application of thiourea and SA+ 2\% Urea increased the phosphorus concentration in seed and straw Further, foliar spray of SA increased phosphorus concentration by $13.76 \%$ in seed and $8.38 \%$ in straw over control. However, it remained statistically at par with $\mathrm{SA}+2 \%$ Urea. The application of chemicals brought about significant improvement in total phosphorus uptake in seed and straw over control. Highest total phosphorus uptake was recorded with $500 \mathrm{ppm}$ thiourea over SA and control and remained at par with $\mathrm{SA}+2 \%$ Urea treatment $\left(\mathrm{S}_{2}\right)$. Similar observation also found by Lakhana et al., (2005) and Yadav (2005).

\section{Effect on potassium content and uptake}

The data (Table 1) indicated that varying fertility levels from 0 to $100 \%$ RDF failed to cause any significant variation in potassium concentration in seed and straw. However, the maximum concentration of potassium in both seed and straw was recorded under 100\% RDF. The potassium uptake by mungbean was found significantly higher with increasing fertility levels up to $75 \%$ RDF. The extent of increase in $\mathrm{K}$ uptake due to $75 \% \mathrm{RDF}$ over control and 50\% RDF was 65.10 and 16.19 per cent, respectively. The fertility levels, $75 \%$ and $100 \%$ RDF remained equally effective with regard to the above parameter. This results obtained are in close conformity with Mondal et al., (2005), Srinivasarao and Ali (2006).

Data further showed that different stress mitigating chemicals could not bring any perceptible variation in potassium content in both seed and straw (Table 1). The data revealed that the foliar spray of agrochemicals brought about significant improvement in potassium uptake by mungbean. The maximum potassium uptake was recorded with $500 \mathrm{ppm}$ thiourea spray. Being at par with $75 \mathrm{ppm} \mathrm{SA}+2 \%$ urea, both these treatments increased the $\mathrm{K}$ uptake by 39.45 and $31.40 \%$ over control, respectively. These similar results also found by Kuttimani and Velayutham (2011). 


\section{Effect on protein content}

Higher nitrogen in seed is directly responsible for higher protein because it is a primary component of amino acids which constitute the basis of protein. Data presented in table 1 showed that protein content in seed was affected significantly due to different levels of fertility, wherein, application of $100 \% \mathrm{RDF}$ $(34.51 \%)$ increased the protein content in seed by, over control, 50\% RDF and $75 \%$ RDF. Higher nitrogen in seed is directly responsible for higher protein because it is a primary component of amino acids which constitute the basis of protein. These results are in cognizance with the findings of Sasode (2008) and Rathore et al., (2010).

A critical examination of data (Table 1) further indicated that the protein content in seed of mungbean was improved significantly by stress mitigating chemicals over control. Foliar application of thiourea $(22.19 \%)$ and $\mathrm{SA}+2 \%(20.31 \%)$ Urea increased the protein content in seed over control. Further, foliar spray of $75 \mathrm{ppm}$ SA increased the protein content in seed by 16.81 per cent over control but it was found at par with $\mathrm{SA}+2 \%$ Urea. Further, foliar spray of $500 \mathrm{ppm}$ thiourea significantly increased the protein content in seed of mungbean (Table 1). This might be due to increased concentration of $\mathrm{N}$ in seed of mungbean by foliar spray of thiourea. These results are in close conformity with the findings of Lakhana et al., (2005) and Yadav (2005).

\section{Effect on yield}

The results indicated that application of fertility levels up to $75 \%$ RDF recorded significantly higher seed, stover and biological yield of mungbean over preceding fertility levels but remained at par with $100 \%$ RDF (Table 2). Application of varying fertility levels at 50, 75 and 100\% RDF enhanced the harvest index over control by $7.73,12.76$ and $14.55 \%$, respectively and remained at par amongst them.

Both nutrients are plays key role in mungbean seed formation and are responsible for keeping the system operating smoothly of mungbean plants, overall an increase in seed, straw, biological yield of mungbean (Meena and Yadav, 2015). In general, NPK were responsible for increased plant height, nodulation pattern, growth and yield parameters or ultimately yields and quality of mungbean. The present results are also in agreement with the findings on legume crops work has been done by several workers (Awomi et al., 2012).

Table.1 Properties of soil

\begin{tabular}{|c|c|c|}
\hline Particulars & Values obtained & Method adopted and references \\
\hline (i) Available $\mathrm{N}\left(\mathrm{kg} \mathrm{ha}^{-1}\right)$ & 128.3 & $\begin{array}{l}\text { Alkaline permanganate method (Subbiah and Asija, } \\
\text { 1956) }\end{array}$ \\
\hline (ii) Available $\mathrm{P}_{2} \mathrm{O}_{5}\left(\mathrm{~kg} \mathrm{ha}^{-1}\right)$ & 16.23 & Olsen’s method (Olsen et al., 1954) \\
\hline (iii) Available $\mathrm{K}_{2} \mathrm{O}\left(\mathrm{kg} \mathrm{ha}^{-1}\right)$ & 154.26 & Flame photometric method (Metson, 1956) \\
\hline (iv) Organic carbon (\%) & 0.18 & Rapid titration method (Walkley and Black, 1947) \\
\hline $\begin{array}{l}\text { (v) EC of saturation extract at } \\
25^{0} \mathrm{C}(\mathrm{dS} / \mathrm{m})\end{array}$ & 1.33 & $\begin{array}{l}\text { Method No. 4, USDA Hand Book No. } 60 \text { (Richards, } \\
\text { 1954) }\end{array}$ \\
\hline $\begin{array}{l}\text { (vi) } \mathrm{pH}(1: 2 \text { soil water } \\
\text { suspension) }\end{array}$ & 8.2 & $\begin{array}{l}\text { Method No. } 21 \text { (b) USDA, Hand Book No. } 60 \\
\text { (Richards, 1954) }\end{array}$ \\
\hline
\end{tabular}


Table.1 Effect of fertility levels and stress mitigating chemicals on nutrient concentration in seed and straw, total uptake and protein content

\begin{tabular}{|c|c|c|c|c|c|c|c|c|c|c|}
\hline \multirow[t]{2}{*}{ Treatments } & \multicolumn{2}{|c|}{$\begin{array}{l}\text { Nitrogen } \\
\text { content }(\%)\end{array}$} & \multirow{2}{*}{$\begin{array}{l}\text { Total } \\
\text { nitrogen } \\
\text { uptake } \\
\left(\mathrm{kg} \mathrm{ha}^{-1}\right)\end{array}$} & \multicolumn{2}{|c|}{$\begin{array}{l}\text { Phosphorus } \\
\text { content }(\%)\end{array}$} & \multirow{2}{*}{$\begin{array}{l}\text { Total } \\
\text { Phosphorus } \\
\text { uptake } \\
\text { (kg/ha) }\end{array}$} & \multicolumn{2}{|c|}{$\begin{array}{l}\text { Potassium } \\
\text { content }(\%)\end{array}$} & \multirow{2}{*}{$\begin{array}{l}\text { Total } \\
\text { Potassium } \\
\text { uptake } \\
\text { (kg/ha) }\end{array}$} & \multirow{2}{*}{$\begin{array}{l}\text { Protein } \\
\text { content } \\
(\%)\end{array}$} \\
\hline & Seed & Straw & & Seed & straw & & Seed & straw & & \\
\hline \multicolumn{11}{|l|}{ Fertility levels } \\
\hline $\mathbf{F}_{0}-$ Control & 2.98 & 1.00 & 41.10 & 0.266 & 0.107 & 3.99 & 0.79 & 1.61 & 35.97 & 18.63 \\
\hline $\mathrm{F}_{1}-\mathbf{5 0 \%} \mathrm{RDF}$ & 3.63 & 1.30 & 62.17 & 0.424 & 0.192 & 8.09 & 0.80 & 1.63 & 42.20 & 22.69 \\
\hline $\mathrm{F}_{2}-75 \% \mathrm{RDF}$ & 3.85 & 1.41 & 74.08 & 0.465 & 0.212 & 9.87 & 0.82 & 1.65 & 46.47 & 24.06 \\
\hline $\mathrm{F}_{3}-100 \% \mathrm{RDF}$ & 4.01 & 1.50 & 81.02 & 0.470 & 0.219 & 10.49 & 0.83 & 1.68 & 48.79 & 25.06 \\
\hline SEm \pm & 0.05 & 0.03 & 1.49 & 0.008 & 0.003 & 0.23 & 0.02 & 0.04 & 1.45 & 0.44 \\
\hline $\mathrm{CD}(\overline{\mathbf{P}}=0.05)$ & 0.15 & 0.08 & 4.29 & 0.023 & 0.010 & 0.66 & NS & NS & 4.20 & 1.27 \\
\hline \multicolumn{11}{|l|}{ Stress mitigating chemicals } \\
\hline$S_{0}-$ Control & 3.15 & 1.03 & 48.10 & 0.356 & 0.167 & 6.50 & 0.79 & 1.60 & 38.37 & 19.69 \\
\hline 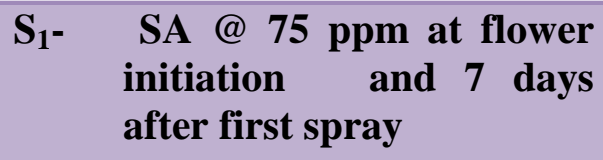 & 3.68 & 1.35 & 66.14 & 0.405 & 0.181 & 8.08 & 0.80 & 1.63 & 43.14 & 23.00 \\
\hline $\begin{array}{ll}S_{2}- & \text { SA @ } 75 \text { ppm + 2\% Urea } \\
& \text { at flower initiation }\end{array}$ & 3.79 & 1.40 & 70.14 & 0.425 & 0.188 & 8.64 & 0.82 & 1.66 & 44.91 & 23.69 \\
\hline $\begin{array}{c}S_{3}-\text { Thiourea @ } 500 \text { ppm at } \\
\text { flowering initiation }\end{array}$ & 3.85 & 1.43 & 73.98 & 0.439 & 0.193 & 9.22 & 0.83 & 1.68 & 47.01 & 24.06 \\
\hline SEm \pm & 0.05 & 0.03 & 1.49 & 0.008 & 0.003 & 0.23 & 0.02 & 0.04 & 1.45 & 0.44 \\
\hline $\mathrm{CD}(\overline{\mathbf{P}}=0.05)$ & 0.15 & 0.08 & 4.29 & 0.023 & 0.010 & 0.66 & NS & NS & 4.20 & 1.27 \\
\hline CV (\%) & 7.22 & 7.15 & 7.97 & 6.72 & 6.58 & 9.74 & 7.50 & 7.52 & 11.61 & 7.19 \\
\hline
\end{tabular}


Table.2 Effect of fertility levels and stress mitigating chemicals on seed, stover and biological yield

\begin{tabular}{|l|c|c|c|}
\hline Treatments & \multicolumn{3}{|c|}{ Yield (kg/ha) } \\
\cline { 2 - 4 } & Seed & Straw & \multicolumn{2}{c|}{ Biological } \\
index $(\%)$
\end{tabular}


The results further indicated that the foliar application of thiourea @ 500 significantly recorded the grain, stover and biological yield and remained at par with SA @ 75 ppm + 2\% Urea at over rest of the treatments (Table 2). However, above treatment significantly highest was recorded with respect to seed yield of mungbean. The beneficial role of thiols (Thiourea and $\mathrm{SA}+2 \%$ Urea), sulphydryl compounds in improving the translocation of photosynthates for yield formation. Thiourea as bio-regulator has potential for increasing crop productivity under environmental stresses, which are mainly high temperature and drought due of changing climate and global warming. These beneficial effect of thiourea and SA $+2 \%$ Urea on the seed yield and yield attributes in crops has also been reported by several research workers (Ali and Mahmoud, 2013, Kumawat et al., 2014).

\section{References}

A.O.A.C. 1960. Official Method of Analysis. Association of Official Analytical Chemists, 1608 Broadnon Drive, Champaign, Illinois, USA

Ali, E.A., and Mahmoud A.M. (2013). Effect of foliar spray by different salicylic acid and zinc concentrations on seed yield and yield components of mungbean in sandy soil. Asian Journal of Crop Science 5 (1): 33-40.

Arora, D. 2004. Effect of thiourea and zinc on growth, yield and quality of barley (Hordeum vulgare L.) Ph.D. Thesis, Rajasthan Agricultural University, Bikaner.

Jackson, M. L. 1973. Soil chemical analysis. Prentice Hall of India Pvt. Ltd., New Delhi, 498.

Kumawat K., Shivran A.C. and kumawat, P. (2014). Effect of bioregulators and phosphorus on yield, economics, nutrient uptake and quality of mothbean
[Vigna aconitifolia (jacq.) Marechal]. Annals of Biology, 30 (1): 98-101.

Kuttimani, R. and Velayutham, A., 2011. Foliar application of nutrients and growth regulators on yield and economics of greengram. Madras Agricultural Journal, 98 (4): 141-143.

Lakhana, R.C.;Gupta, A.K.; Shivran, A.C. and Shivran, R.K. 2005. Role of thiourea in improving the dry matter partitioning, yield and quality of pearlmillet [Pennisetum glaucum (L.) R Br. emend. Stuntz]. Annals of AgriculturalResearch.26 (2): 218-223.

Meena, R. S. and Yadav, R. S. (2015). Yield and Profitability of Groundnut (Arachis hypogaea L) As Influenced by Sowing Dates and Nutrient Levels With Different Varieties. Legume Research, 38 (6): 791-797.

Metson, A. I. 1956. Method of chemical analysis for survey samples. Bulletin No. 2 Department Science. Mediterranean Research Soil Bureau 12.

Mondal, S., Biswal, K.C. and Jana, P.K. 2005. Yield, economics, nutrient uptake and consumptive use of water by summer green gram [Vigna radiata (L.) Wilczek] as influenced by irrigation and phosphorus application. Legume Research 28 (2): 131-133.

Olsen, S.R., Cole, C.V., Watanable, F.S. and Dean, L.A. 1954. Estimation of available phosphorus in soils by extraction with sodium bicarbonate. Circular, United States Department of Agriculture, p. 932.

Rathore, D.S., Purohit, H.S. and Yadav, B.L. 2010. Integrated phosphorus management on yield and nutrient uptake of urdbean (Vigna mungo L.) under rainfed condition of southern Rajasthan. Journal of Food Legumes, 23 (2): 128-131.

Richards, L.A. 1954. Diagnosis and 
Improvement of Saline and Alkaline Soils, USDA Hand Book no. 60, Oxford and IBH Pub. Co., New Delhi.

Sasode, D.S. 2008. Response of green gram [Vigna radiata $(\mathrm{L}$.$) Wilczek] to fertility$ levels and sulphur sources application. Agricultural Science Digest 28 (1): 1821.

Singh, B. and Pareek, R.G. 2003. Effect of phosphorus and biofertilizers on growth and yield of mungbean. Journal of Food Legumes 16: 31-33.

Snell, P.D. and Snell, G.T. 1949. Colorimetric methods of analysis, $3^{\text {rd }}$ Edn. Vol.II D. Van Nostrand Co. Inc., New York.

Srinivasarao, C. and Ali, M. 2006. Response of nutrient uptake of urdbean and mungbean genotypes to optimum nutrient supply on nutrient deficient sandy loam soil. Journal of Food Legumes 19 (2): 259-262.
Subbiah, B.V. and Asija, G.I. 1956. A rapid procedure for the estimation of available nitrogen in soils. Current Science 25: 259-260.

Walkley and Black, I. A.1947. Estimation of soil organic carbon by the chromic acid titration method. Soil Sciences, 37: 29 38.

Yadav, L.R. 2005. Effect of bioregulators on productivity of wheat [Triticum aestivum (L.)] varieties under normal and late sown conditions. Ph.D. Thesis, Rajasthan Agricultural University, Bikaner.

Yakadri, M., Tahatikunta, R. and Latchanna, A. 2004. Dry matter production and nutrient uptake of green gram [Vigna radiata (L.) Wilczek.] as influenced by nitrogen and phosphorus during wet season. Legume Research 27: 58-61.

\section{How to cite this article:}

Sarita, O.P. Sharma, U.N. Shukla, Saroj Kumari Yadav and Roshan Kumawat. 2019. Effect of Fertility Levels and Stress Mitigating Chemicals on Nutrient Uptake, Yield and Quality of Mungbean [Vigna radiata (L.) Wilczek] under Loamy Sand Soil of Rajasthan. Int.J.Curr.Microbiol.App.Sci. 8(05): 965-974. doi: https://doi.org/10.20546/ijcmas.2019.805.113 